\title{
Phenylcoumarins from Kielmeyera elata
}

\author{
R. da S. Gramacho ${ }^{a}$, Tanus J. Nagem ${ }^{\mathrm{b}, *}$, Tânia Toledo de Oliveira ${ }^{\mathrm{a}}$, Maria Eliana \\ L. R. de Queiroz ${ }^{\mathrm{c}}$, Antonio A. Neves ${ }^{\mathrm{c}}$, Nagib Saddi ${ }^{\mathrm{d}}$

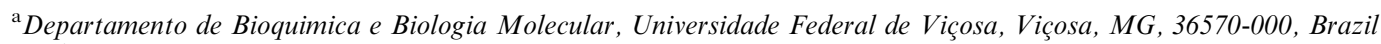 \\ ${ }^{\mathrm{b}}$ Departamento de Quimica ICEB, Universidade Federal de Ouro Preto, Ouro Preto, MG, 35400-000, Brazil \\ ${ }^{\mathrm{c}}$ Departamento de Quimica, Universidade Federal de Viçosa, Viçosa, MG, 36570-000, Brazil \\ ${ }^{\mathrm{d}}$ Herbario Central, Universidade Federal de Mato Grosso, Cuiabá, Brazil
}

Received 12 March 1998; accepted 27 July 1998

\begin{abstract}
Friedelin, the 4-phenylcoumarins mammeisin, 4-phenyl-5-hydroxy-6-(3-methyl-1-oxobutyl)-2'-(1-hydroxy-1-methylethyl)-3',4'dihydro $\left(5^{\prime}, 4^{\prime}: 7,8\right)$ furancoumarin, and mammeigin have been purified from the stem of Kielmeyera elata. These compounds have previously been reported for the same species. In addition, a new derivative of mammeigin has been isolated and identified as 4phenyl-5-hydroxy-6-(3-hydroxymethyl-1-oxo-butyl)-2',2'-dimethyl(6',5':7,8)pyrancoumarin. (C) 1999 Elsevier Science Ltd. All rights reserved.
\end{abstract}

Keywords: Kielmeyera elata; Guttiferae; phenylcoumarins; hydroxymammeigin

\section{Introduction}

This paper is a study of Kielmeyera elata, Saddi, as part of a broader study of the Guttiferae family. The plant has been collected and identified by Dr. Nagib Saddi, (Central Herbarium, Universidade Federal do Mato Grosso, Cuiabá, Brazil), in Ilhéus, Bahia ${ }^{1}$, Brazil.

Several species of this genus have been shown to contain xanthones and coumarins (Peres, 1997; Nagem \& Silva, 1988; Moreira, Jesus \& David, 1996; Moreira, Guedes \& Chavez, 1997; Santos, Araujo \& David, 1996; Santos, Guedes \& Chavez, 1997). This study has revealed the presence of friedelin and of three known 4-phenylcoumarins: mammeisin (Crombie, Games \& McCormick, 1966; Carpenter, McGarry \& Scheinmann, 1971; Bandaranayake, Selliah, \& Sultanbawa, 1975), 4-phenyl-5-hydroxy-6-(3-methyl-1oxo-butyl)-2']-1-hydroxy-1-methylethyl)-3',4'-dihydro $\left(5^{\prime}, 4^{\prime}: 7,8\right)$ furancoumarin (Bandaranayake, Selliah,

\footnotetext{
* Corresponding author.

${ }^{1}$ Herbarium material: Santos, T.S. ${ }^{\circ} 4583$.
}

\& Sultanbawa, 1975; Crombie, Games \& Haskins, 1972; Silva, 1986) and mammeigin (1) (Nagem \& Silva, 1988; Finnegan \& Mueller, 1965; Crombie, Games \& McCormick, 1967) as well as a new coumarin derivative of mammeigin which was given the trivial name of hydroxymammeigin (2).

\section{Results and discussion}

The IR spectrum of hydroxymammeigin (2) showed bands at $3440 \mathrm{~cm}^{-1}$ (chelated hydroxyl), $1740 \mathrm{~cm}^{-1}(\alpha-$ pyrone) and $700 \mathrm{~cm}^{-1}$ (monosubstituted benzene nucleus). Its NMR spectrum revealed a signal at $\delta$ 5.98 (s) for one hydrogen on $\mathrm{C}-3$ and signals at $\delta 7.38$ and $7.29(\mathrm{~m})$ due to the aromatic hydrogens. The absence of a signal at $\delta 7.5-8.3$ is due to the presence of a phenyl group at the C-4 position (Santos, Guedes $\&$ Chavez, 1997). A singlet at $\delta 1.57$ integrated for six hydrogens and the presence of two doublets of one hydrogen each at $\delta 8.62(\mathrm{~J}=10.1 \mathrm{~Hz})$ and at $\delta 6.88$ $(\mathrm{J}=10.1 \mathrm{~Hz})$ established the presence of a 2,3dimethyl- $\Delta^{3}$-pyran ring. 


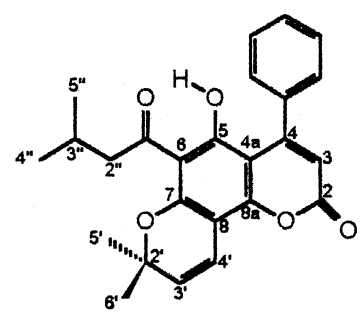

1

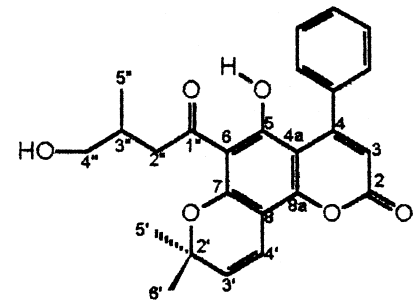

2
The presence of the $[\mathrm{M}-15]^{+}$base peak in the mass spectrum has also strengthened this conclusion. The signals at $\delta 3.20(1 \mathrm{H}$. dd $\mathbf{J}=16.4$ and $6.6 \mathrm{~Hz}) . \delta 3.05$ $(1 \mathrm{H}, \mathrm{dd}, \mathrm{J}=16.4$ and $6.6 \mathrm{~Hz}), \delta 3.57(1 \mathrm{H}, \mathrm{dd}, \mathrm{J}=10.6$ and $5.3 \mathrm{~Hz}), \delta 350(1 \mathrm{H}$, dd. $\mathbf{J}=10.4$ and $5.3 \mathrm{~Hz})$ and $\delta 0.98(3 \mathrm{H} \mathrm{d}, \mathrm{J}=6.8 \mathrm{~Hz})$ revealed the presence of a 3 hydroxymethyl-1-oxobutyl group, which has been confirmed by mass spectrum high-intensity peak $[\mathrm{M}-18]^{+}$ resultant of water loss. The signal at $\delta 14.55(1 \mathrm{H}, \mathrm{s})$ has been ascribed to a hydroxyl group chelated to an acyl group. The angular fusion of the chromene ring has been determined by comparison with mammeigin since both compounds have given signals corresponding to the six hydrogens in the dimethylchromene group at $\delta 1.57$. Additionally, mammeigin and hydroxymammeigin have a green color with methanolic $\mathrm{FeCl}_{3}$ solution and a similar chemical shift occurred due to the acyl group present at the $\mathrm{C}-6$ position in the coumarin skeleton. From these data. we propose that compound (2) 4-phenyl-5-hydroxy-6-(3-hydroxymethyl-1-oxo-butyl)-2', $2^{\prime}$-dimethyl $\left(6^{\prime}, 5^{\prime}: 7,8\right)$ pyrancoumarin, which, to our knowledge, has never been reported before.

\section{Experimental}

Mps: Quimis, mod 340D23; CC: Kieselgel (0.07-0.23 $\mathrm{mm})$; TLC: Kieselgel GF 254 60, spots, were visualized with phosphoromolybdic acid, seric sulphate and UV fluorescence; IR: only major bands are quoted.

Constituent isolation. $3.2 \mathrm{~kg}$ of stems of Kielmeyera elata were submitted to successive extractions with hexane, by mechanical agitation under room temperature. After the removal of the solvent $9.41 \mathrm{~g}$ of the extract was chromatographed with silica gel $(180 \mathrm{~g})$ using hexane, ethyl ether and ethanol as eluents. Several fractions were collected and separated into 11 groups $\left(\mathrm{H}_{1}-\mathrm{H}_{11}\right)$ by TLC. $\mathrm{H}_{3}$ group $(1.06 \mathrm{~g})$ was chromatographed with silica gel $(40 \mathrm{~g})$ using hexane, ethyl ether and ethanol as eluents and produced eight subgroups. The $\mathrm{H}_{3.4}$ subgroup was washed with hexane, and recrystallised in hexane/chloroform, giving friedelin $(0.025 \mathrm{~g}) . \mathrm{H}_{3.5}$ and $\mathrm{H}_{3.6}$ were repeatedly washed with hexane and purified by repeated TLC (silica gel, hexane, chloroform, methanol 60:20:20) to give mammeigin (1) $(0.2 \mathrm{~g})$. After several chromatographies of $\mathrm{H}_{4}$ (4.27 g) using silica gel, hexane, chloroform and ethanol as eluents, 4-phenyl-5-hydroxy-6-(3-methyl-1oxo-butyl)-2'-(1-hydroxy-1-methylethyl)-3', 4'-dihy-

dro $\left(5^{\prime}, 4^{\prime}: 7,8\right)$ furancomnarin was obtained. The remaining material from the extraction with hexane was repeatedly extracted with acetone, at room temperature. The extract obtained $(160 \mathrm{~g})$ was solubilized in chloroform yielding two phases after filtration. The chloroform solubles were concentrated to $75.38 \mathrm{~g}$ and chromatographed with silica gel (1500 g) using hexane, ethyl acetate, ethanol and methanol as eluents. Several fractions were obtained $\left(\mathrm{A}_{1}-\mathrm{A}_{21}\right)$ by TLC. $\mathrm{A}_{1}$ was washed with ethyl acetate and recrystallised in an ethyl acetate/chloroform mixture which provided friedelin $(0.20 \mathrm{~g}) . \quad A_{3}-A_{8}$ were repeatedly washed with petroleum ether and recrystallised in a hexane/chloroform mixture to give an additional amount of mammeigin (1) $(5.5 \mathrm{~g}) . \mathrm{A}_{12}$ and $\mathrm{A}_{13}$ were washed with diethyl ether and recrystallised in hexane/acetone, and provided 4phenyl-5-hydroxy-6-(3-methyl-1-oxo-butyl)-2'-(1hydroxy-1-methylethyl)-3', $4^{\prime}$ dihydro( $\left.5^{\prime}, 4^{\prime}: 7,8\right)$ furancoumarin. $\mathrm{A}_{14}$ was washed with ethyl ether and recrystallised in hexane/chloroform producing 4-phenyl-5hydroxy-6-(3-hydroxymethyl-1-oxobutyl)-2', 2'dimethyl $\left(6^{\prime}, 5^{\prime}: 7,8\right)$ pyrancoumarin (2) $(0.23 \mathrm{~g})$.

Hydroxymammeigin (2). Yellow needles, mp 174$176^{\circ}$ hexane/chloroform), UV $\lambda_{\text {max }}^{\mathrm{MeOH}} \mathrm{nm}(\log \varepsilon): 232$ (4.53), 284 (4.60), 335 (3.94); $\lambda_{\max }^{\mathrm{max}+\mathrm{NaOH}} \mathrm{nm}(\log \varepsilon)$ 252 (4.45), 308 (4.48), 405 (3.78); acidification reversed the shifts: $\lambda_{\max }^{\mathrm{MeOH}+\mathrm{NaOAc}} \mathrm{nm}(\log \varepsilon): 232$ (4.48), 286 (4.51), 336 (4.07); $\lambda_{\max }^{\mathrm{MeOH}+\mathrm{NaOAc}+\mathrm{H}_{3} \mathrm{BO}_{3}} \mathrm{~nm}$ identical to the spectrum in $\mathrm{MeOH} ; \lambda_{\max }^{\mathrm{MeOH}+\mathrm{AlCl}_{3}} \mathrm{~nm}$ : identical to the spectrum in MeOH; IR $v_{\max }^{\mathrm{KBr}} \mathrm{cm}^{-1} 3440$ (br), 1740, $1720,1600,1590,1380,1260,1125,78 \mathrm{O}, 750,700 ;{ }^{1} \mathrm{H}$ NMR $\left(400 \mathrm{MHz}, \mathrm{CDCl}_{3}\right): \delta 0.98(3 \mathrm{H}, \mathrm{d}, \mathrm{J}=6.8 \mathrm{~Hz}$, H-5"), $1.57\left(6 \mathrm{H}, \mathrm{s}, \mathrm{H}-5^{\prime}\right.$ and $\left.\mathrm{H}-6^{\prime}\right), 2.35(1 \mathrm{H}, \mathrm{m}, \mathrm{H}-$ $\left.3^{\prime \prime}\right), 3.05\left(1 \mathrm{H}, \mathrm{dd}, \mathrm{J}=16.4,6.6 \mathrm{~Hz}, \mathrm{H}-2 \mathrm{a}^{\prime \prime}\right), 3.20(1 \mathrm{H}$, $\left.\mathrm{dd}, \mathbf{J}=16.4,6.9 \mathrm{~Hz}, \mathrm{H}-2 \mathrm{~b}^{\prime \prime}\right), 3.50(1 \mathrm{H}, \mathrm{dd}, \mathrm{J}=10.4,6.3$ $\left.\mathrm{Hz}, \mathrm{H}-4 \mathrm{a}^{\prime \prime}\right), 3.57\left(1 \mathrm{H}, \mathrm{dd}, \mathrm{J}=10.6,5.3 \mathrm{~Hz}, \mathrm{H}-4 \mathrm{~b}^{\prime \prime}\right) 5.62$ $\left(1 \mathrm{H}, \mathrm{d}, \mathrm{J}=10.1 \mathrm{~Hz}, \mathrm{H}-2^{\prime}\right), 5.98(1 \mathrm{H}, \mathrm{s}, \mathrm{H}-3), 6.88$ $\left(1 \mathrm{H} . \mathrm{d}, \mathrm{J}=10.1 \mathrm{~Hz}, \mathrm{H}-1^{\prime}\right), 7.30$ and $7.38(2 \mathrm{H}, \mathrm{m}$ and $\left.3 \mathrm{H}, \mathrm{m},-\mathrm{C}_{6} \mathrm{H}_{5}\right), 14.55(1 \mathrm{H}, \mathrm{s}, \mathrm{H}-5)$; EIMS (probe) $70 \mathrm{ev}$ $\mathrm{m} / \mathrm{z}$ (rel. int.): $420[\mathrm{M}]^{+} \cdot(2), 402\left[\mathrm{M}-\mathrm{H}_{2} \mathrm{O}\right]^{+} \cdot(65), 387$ $\left[\mathrm{M}-\mathrm{H}_{2} \mathrm{O}-\mathrm{Me}\right]^{+}(100), 359[\mathrm{M}-\mathrm{Me}-\mathrm{CO}]^{+}$(5), 334 (12), 331 (16), 303 (4), 165 (5), 77 (5). The compound gave an olive-green color with methanolic $\mathrm{FeCl}_{3}$.

\section{Acknowledgements}

The authors would like to thank the botanist André Maurício de Carvalho (Herbarium of Centro de pesquisas do Cacau da Comissão Executiva do Plano da Lavoura Cacaueira - CEPEC - CEPLAC - Ilhéus - 
$\mathrm{Ba}$ - Brasil) for locating the plant. The Voucher specimen is located in Herbarium Central- $\mathrm{n}^{\circ} 4583$, classified by Santos, T. S. We are indebted to Conselho Nacional de Desenvolvimento Cientifico e Tecnológico $(\mathrm{CNPq})$, Fundação de Amparo a Pesquisa do Estado de Minas Gerais (FAPEMIG), Coordenação de Aperfeiçoamento Pessoal de Ensino Superior (CAPES) and Universidade Federal de Viçosa (UFV) for financial aid.

\section{References}

Bandaranayake, W. M., Selliah, S. S., \& Sultanbawa, M. U. S. (1975). Phytochemistry, 14, 265.

Carpenter, I., McGarry, E.J. and Scheinmann, F. (1971) Journal Chemical Society (C), 3783.

Crombie, L., Games, D. E., \& Haskins, N. J. (1972). Journal Chemical Society, Perkin I, 18, 2248.

Crombie, L., Games, D. E., \& McCormick, A. (1966). Tetrahedrom Letters, 2, 145 .
Crombie, L., Games, D. E., \& McCormick, A. (1967). Journal Chemical Society (C), 23, 2553.

Finnegan, R. A., \& Mueller, W. H. (1965). Journal Organic Chemistry, 30(7), 2342.

Moreira, L.M., Guedes, M.S.L. and Chavez, J.P. (1997) In: Annual meeting of Sociedade Brasileira de Química, Poços de Caldas, Brazil.

Moreira, L.M., Jesus, J.A. and David, J.M. (1996) In: Annual meeting of Sociedade Brasileira de Química, Poços de Caldas Brazil.

Nagem, T. J., \& Silva, M. A. (1988). Phytochemistry, 27(9), 2961.

Peres, V., Xantonas: Revisão geral e estudo por RMN ${ }^{1} \mathrm{H}$. Belo Horizonte: UFMG, (1997). Ph.D Thesis, Universidade Federal de Minas Gerais, Brazil.

Santos, N.A., Araujo, H.R.A. and David, J.M. (1996) In: Annual meeting of Sociedade Brasileira de Química, Poços de Caldas, Brazil.

Santos, N.A., Guedes, M.S.L. and Chavez, J.I.P. (1997) In: Annual meeting of Sociedade Brasileira de Química, Poços de Caldas, Brazil.

Silva, M. A., Estudo químico de Kielmeyera pumila. Belo Horizonte: UFMG, (1986). Ms.D Thesis, Universidade Federal de Minas Gerais, Brazil. 